\title{
Die Bybel aan die universiteit en in die kerk
}

GMM Pelser

Universiteit van Pretoria

\begin{abstract}
The Bible at the university and in the church

The question is posed as to the difference between the theological faculty and the church with regard to their respective approaches to and uses of the Bible. By means of a number of theses it is demonstrated that the respective approaches are actually quite different, resulting in a gap between faculty and church. Due to the scientific orientation and mission of the faculty, however, this gap is unavoidable and even necessary. Even so, this gap should not become of such a nature as to lead to estrangement. To counter this danger, resent insights and developments regarding the study of the Bible should be conveyed to the church, however in a constructive and comprehensible manner. To this venture faculty members and church ministers are equally responsible.
\end{abstract}

\section{DIE UNIVERSITEIT}

Laat my ter aanvang eers daarop wys dat wat die vraag na die Bybel aan die universiteit betref, daar in hierdie bydrae nie gehandel sal word oor die vraag of die bestudering van die Bybel naas ander dissiplines noodsaaklik en van betekenis is vir die universiteitswese as sodanig nie. Waarom dit in hierdie bydrae gaan, is dat probeer uitgemaak moet word wat dit presies behels of veronderstel is om te behels wanneer die Bybel in die akademies-wetenskaplike konteks van 'n universiteit bestudeer word. 
Hierdie vraag bring op sigself die volgende twee vrae na vore:

Verstaan ons hieronder bloot die 'objektiewe' of 'neutrale' bestudering van die Bybel soos in die geval van enige ander studie-objek, en dan miskien as onderdeel van religieuse studies of godsdienswetenskap?

$$
\text { of }
$$

Verstaan ons hieronder 'n 'teologiese' onderneming met die oog op die beskikbaarmaking van die resultate daarvan vir die Christelike teologie of vir teoloë (predikante) in die Christelike kerk.

Laasgenoemde vraag kan ook weer op twee moontlikhede dui, naamlik:

* teologie sonder denominasionele bepaaldheid en gerigtheid;

* teologie bepaal deur 'n denominasionele teologiese tradisie en toegespits op of ten dienste van daardie denominasie.

Die twee moontlikhede wat eerste hierbo genoem is, het natuurlik te doen met die alternatiewe what it meant en what it means met betrekking tot die Bybel. In eersgenoemde geval sal die bestudering van die Bybel bloot 'n deskriptiewe onderneming wees, sonder die bedoeling dat die resultate van hierdie studie tot een of ander commitment moet lei. Dit sal min of meer die praktiese uitvoering wees van die standpunt van William Wrede (1859-1906), naamlik dat slegs gevra moet word na die Religion waarvan die Bybel die skriftelike neerslag is, dit wil sea bloot die vraag na wat die mense van die Bybelse tye geglo, gedink, geleer, gehoop, vereis en na gesoek het. Dit is 'n bestudering van die Bybel wat volgens Wrede vry moet wees van enige gedagte van die normatiwiteit van die Skrif of van die verpligting om iets opbouends vir die kerk daar te stel.

Hoewel daar oor en vir hierdie benadering beslis baie gesê kan word, wil ek my nie daaroor uitlaat nie, aangesien ek my wil bepaal by die situasie waar die Bybel wel aan 'n universiteit bestudeer word met die doel om resultate op te lewer wat bruikbaar is vir die Christelike teologie.

Die moontlikheid dat die Bybel wel teologies bestudeer word maar sonder 'n spesifieke denominasionele bepaaldheid of gerigtheid, is naturlik lank reeds praktyk, veral aan universiteite in die VSA en ook hier te lande by Unisa en ander. 
Wat die situasie van die Nederduitsch Hervormde opleiding aan die Universiteit van Pretoria betref, kan daar vanselfsprekend slegs sprake wees van die hantering en bestudering van die Bybel in opdrag van en ten dienste van die teologie en verkondiging van die Kerk. Dit geld natuurlik nie alleen die Bybelwetenskappe nie, maar ook die ander teologiese dissiplines. Oor hoe die Bybel deur die nie-Bybelwetenskappe in die Fakulteit Teologie gebruik word en behoort te word, wil en kan ek my nie hier uitlaat nie. Wat die Bybelwetenskappe betref, gaan ek, sonder om daarop aanspraak te maak dat dit 'n juiste weergawe van die situasie is, die saak met die volgende stellings probeer skets:

\subsection{Hoe word die Bybel beskou?}

- Hermeneuties word daar uitgegaan van die vooronderstelling dat die Bybel die Woord van God is.

- Dit word egter nie beskou as identies met of gelyk aan die Woord van God nie maar as menslike getuienis daarvan.

- Hierdie menslike getuienis is die neerslag van menslike geloofsverstaan van wat die gelowiges van Bybelse tye gemeen en geglo het die selfbetuiging van God aan hulle was. Hoe hierdie selfbetuiging presies plaasgevind het, is egter nie vir ons moontlik om uit te maak nie.

- Hierdie getuienis is gelewer oor 'n lang periode en onder verskillende historiese omstandighede, sodat dit ook as histories bepaald gesien moet word.

- Historiese bepaaldheid of kontingentheid raak veral ook sake soos sosiale strukture, gebruike en voorskrifte asook sekere etiese norme wat vandag kwalik as aanvaarbaar beskou kan word.

- Die verskillende historiese situasies het verskillende geloofsverstaan tot gevolg gehad asmede die herinterpretasie en aanpassing van bestaande konsepte juis met die doel om 'n bepaalde situasie aan te spreek.

- Die menslikheid van die Bybel kom ook tot uitdrukking in die verskeidenheid van interpretasies van dieselfde gebeure of handeling van God - en 
hierdie verskeidenheid is dikwels onharmoniseerbaar en soms selfs teenoorstaande of teenstrydig.

Die menslikheid kom verder tot uitdrukking in die duidelik herkenbare tendensieusiteit waarin een teologiese posisie hom polemies teen die ander gestel of daarteen afgegrens het. Daar is dus ook 'menslikhede' in die Bybel wat kwalik in verband gebring kan word met die Woord van God.

- In die geval van 'teologiese ontwikkeling' blyk 'n bepaalde ontwikkeling soms nie 'n legitieme uitbouing van 'n (die) vorige te wees nie maar eerder 'n verarming of afwyking daarvan.

- Inhoudelik blyk die Bybel ook dikwels nie enig in sy soort te wees nie, maar 'n teks waarin elemente van ander tekste opgeneem is. Intertekstualiteit is dus 'n wesenlike saak waarby nie verbygekyk kan word nie.

- Daar is verder die probleem van redaksie en gevolglik van die eenheid en integriteit van bepaalde geskrifte sowel as die vraag na interpolasies en glosses.

* In die lig van sy verskeidenheid is dit onteenseglik dat die Bybel verskillende teologieë akkommodeer wat weer die moontlikheid daarstel vir denominasionele verskeidenheid.

- As gevolg van al hierdie werklikhede word die Bybel nie in al sy dele as onfeilbaar beskou nie en word sy gesag ook nie meganies of outomaties aanvaar nie maar eers by die hoor en verstaan van God se woord daarin.

1.2 Hoe word die Bybel hanteer

* Hoewel uitgaande van die vooronderstelling dat die Bybel die Woord van God is, word dit prakties soos 'n 'teologie' handboek hanteer.

* Aangesien dit 'n versameling van verskillende tekssoorte is wat histories ontstaan het en waarin van kontemporêre kommunikasiestrategieë gebruik gemaak is, word dit tegnies soos enige ander teks uit daardie tyd gelees. Vir die verstaan daarvan word derhalwe uitgegaan van dieselfde literatuur- 
teoretiese uitgangspunte as wat in die algemene literatuurwetenskap geld en dieselfde toepasbare metodes van interpretasie word gebruik as wat vir vergelykbare nie-Bybelse literatuur gebruik word.

- Vir die vraag na die wat van die betekenis van Bybelse tekste is die vraag na die hoe van betekenis dus van die uiterste belang.

- Dit beteken ook dat vir sover die Bybel hom as 'n historiese dokument aanbied, hy aan dieselfde historiese vraagstelling en kritiek onderwerp word as enige ander dokument uit die verlede. Daar word gevra na historiese waarskynlikhede, ondersoek ingestel na die zeitgeschichtliche met alles wat dit behels, na kragte, tendense en strominge, na kontingente situasies, opvattings en voorstellings, na ontwikkelingslyne en die teologiese legitimiteit daarvan, ensovoorts.

- Veral ten upsigte van vertelmateriaal word die wêreld van die teks as vertelde wêreld gehanteer en nie as 'n wêreld in 'n een tot een verhouding met die werklikheid nie, as 'n fotokopie van die werklikheid nie. Die tekste word dus as 'n weerspieëling van die werklikheid gesien en nie as 'n venster op die werklikheid nie.

- In die soeke na wat die tekste wil kommunikeer, word nie net gevra na die teks nie maar ook na die konteks, en dan nie slegs die konteks van ontstaan nie, ook die konteks van resepsie.

- Daar word van die standpunt uitgegaan dat die teks alleen werklik kan kommunikeer as die wêreld van die teks en die van die leser of eksegeet met mekaar versmelt.

- Dit hou in dat betekenis nie eensydig deur die teks alleen gegenereer word nie maar in die hermeneutiese sirkelproses, in die wisselwerking tussen teks en eksegeet. Hier speel die vooronderstellings (Enwartungshorizont) van die eksegeet 'n onontkenbare, onontwykbare en belangrike rol, hoewel aanvaar word dat die teks as die eintlike subjek van kommunikasie, die voorrang het.

- Vanweë die feit van die inherente meerduidigheid van tekste asmede die rol wat vooronderstellingsbepaalde resepsie speel, word aanvaar dat daar nie so iets is as dié betekenis van 'n teks nie en word ook nie gepoog om betekenis 
vir eens en vir altyd vas te stel nie. Uit die geskiedenis van die resepsie van tekste is dit immers duidelik dat tyd, omstandighede en soorte lesers verskillende verstaan van tekste ten gevolg gehad het. En elke verstaan is streng gesproke 'n nuwe teks.

* In die lig hiervan kan nie vooraf voorgeskryf word hoe die Bybelse teks verstaan moet word nie. Dit bly afhanklik van die relasionele verhouding tussen teks en eksegeet. Daarom dat dit korrek is om te sê dat die waarheid van die Skrif relasioneel is.

- $\quad \mathrm{Na}$ alles en bo alles is die verstaan van die Bybelse teks nie 'n saak van die willekeur van die eksegeet nie maar van die Gees wat die eintlike verstaanbaarmaker van die teks is, hoewel sy werk by die verstaan van die teks net so onnaspeurbaar is as by die ontstaan daarvan.

\subsection{Die praktiese gevolge}

Prakties kom die bogenoemde beskouing en hantering van die Bybel op die volgende neer:

* Die eenheid van die Bybel is relatief. Daar kan hoogstens gepraat word van 'n eenheid in verskeidenheid, en dikwels dring die verskeidenheid hom sterker op die voorgrond as die eenheid. Verskeidenheid as sodanig word egter nie as negatief ervaar nie. Dit word eerder gesien as die resultaat van die dinamiek van God se handelinge met die mense en die mense se antwoord op hierdie handelinge.

* Die gesag van die Bybel hang af van die interpretasie daarvan. Daar is dus nie so iets as meganiese gesag vór die hoor en verstaan van die Woord van God nie.

* Die Bybel is die Woord van God in mensewoorde. Dit is dus nie gelyk aan die Woord van God nie maar alleen draer daarvan. Dit is Woord van God vir sover die woord van God daarin gehoor word.

- Die formele kanon is nie gelyk aan die prinsipiële kanon nie. Die kanon is dus nie in al sy dele ewe gesagvol nie. Daarom is die onvermydelike dat 
altyd met 'n kanon in die kanon gewerk word.

- Sommige Bybelse voorstellings en uitsprake is so histories kontingent dat dit nie meer vir vandag iets te sê het nie.

- Die Bybel kan daarom nie gewoon fundamentalisties op elke hedendaagse situasie toegepas of afgedwing word nie. Dit kan derhalwe nie as norm vir elke situasie of saak dien nie. Dikwels word ook sonder die Bybel probleemoplossend te werk gegaan, soms in teenspraak met bepaalde Bybelse voorskrifte. Wat dus voorskrywend vir 'n Bybelse situasie was, word nie altyd as voorskrywend vir latere situasies ervaar en aanvaar nie.

* Die vooronderstellings en situasie van die eksegeet speel so 'n groot rol dat die aansprake van die Bybel telkens opnuut geïnterpreteer word. Wat die Bybel dus móre vir ons sal sê, weet ons nie nou al nie. Ook kan ons nie vir ander voorskryf wat die Bybel vandag of môre vir hulle moet sê nie. Ons kan alleen deur intersubjektiewe konsensus tot op sekere hoogte tot 'n gemeenskaplike verstaan van die Bybel kom. In die praktyk is verskillende verstaan van die Bybel vanuit eie verstaanshorison egter 'n feit wat tot op denominasionele vlak vergestalt. So kom wat in elke tyd, situasie en kring relasioneel as waar en gesagvol ervaar word, in die teologiese en geloofspraktyk tot uitdrukking en word sodoende 'n verskeidenheid en selfs uiteenlopendheid van verstaan deur dieselfde Bybel geakkommodeer.

- Na alles bly die aanspraak, die gesag en die saak van die Bybel gehandhaaf. Dit geld trouens juis soveel sterker as dit in die hede verstaanbaar by mense tuisgebring kan word en hulle tot geloofsverstaan en so tot Christelike eksistensie kan bring.

\section{DIE KERK}

Vir sover die situasie van die Bybel in universitere konteks hierbo korrek weergegee is, is dit vanselfsprekend dat gesien die tradisionele opvatting oor die Bybel in die Kerk, baie predikante en bykans alle ander ampsdraers en lidmate die saak as verontrustend sal ervaar. By die oorgrote meerderheid ampsdraers en veral lidmate is dit naamlik so dat die Bybel steeds beskou word as: 
* gelyk aan die Woord van God

* meganies gesagvol in al sy dele

* bevattende ewige en onveranderlike waarhede

* meganies geïnspireer

* onfeilbaar in al sy dele

* 'n getroue weergawe van die werklikheid

* 'n eenheid

* toepasbaar in elke situasie

* en lesbes, vir sommige, 'n magiese voorwerp.

Hierby moet egter seker ook gesê word dat daar wel 'n aantal lidmate is wat nie sonder vrae oor hierdie aangeleenthede is nie. Dat daar beslis ook iets deurgewerk het vanaf die Fakulteit na die Kerk, kan nie ontken word nie. Nietemin lyk dit ook onontkenbaar dat daar 'n aansienlike kloof tussen Fakulteit en Kerk bestaan en dat hierdie kloof oor die afgelope paar dekades groter geword het. En dit veral omdat daar 'n fenominale ontwikkeling in teksteorie en in die teologie plaasgevind het.

Laat my egter daarop wys dat daar altyd 'n kloof of 'n afstand tussen Fakulteit en Kerk sal wees en moet wees. Die Fakulteit sal uit die aard van sy opdrag altyd op die voorpunt van ontwikkelinge moet bly. En die Kerk moet die Bybel ook altyd, om so te sê, op 'n naïewer wyse beskou en hanteer as wat die Fakulteit dit doen. Nogtans flikker die rooi ligte as die Fakulteit nie daarop ingestel is of dit nie regkry om die Kerk saam met hom te neem rondom die Bybel nie. Dit behoort gedoen te word deur bevatlike geskrif, maar veral deur die predikante wat deur die Fakulteit die Kerk ingestuur word. Die predikante is die belangrikste brug van die Fakulteit na die Kerk. Daarom rus daar op die predikante die verantwoordelikheid om te sorg dat hulle sover as moontlik op hoogte bly van ontwikkelinge sodat hulle hierdie belangrike funksie kan vervul.

Hoewel die Kerk nie verskoon kan word as hy onwillig is om hom met nuwere ontwikkelinge in die beskouing en hantering van die Bybel te vereenselwig nie, rus die onus om die Kerk hiervan te oortuig nogtans in die grootste mate op die skouers van die Fakulteit. Natuurlik kan die insigte van die Fakulteit en die resultate van sy studiewerk nie net so in die skoot van die Kerk gegooi word nie. Ons het in Fakulteit en Kerk te doen met twee wêrelde wat eenvoudig nie op dieselfde vlak beweeg nie. Daarom sal die denke van die Fakulteit anders in die Kerk tot uitdrukking gebring moet word as wat dit in die lesingkamer of in wetenskaplike diskussie gebeur. Maar daar is ook elemente van die saak wat by die Fakulteit moet bly en nie aan die Kerk oorgedra hoef te word nie. 
Slegs wat werklik essensieel is en wat opbouend vir die geloof kan wees, moet tot kennis van die lidmate gebring word. Wat oorgedra moet word en wat nie, is natuurlik nie maklik om oor te besluit nie en sal oor verskil word. Belangrik is egter dat nie van die lidmate weerhou mag word wat hulle moet hoor nie. Ook in hierdie opsig is die woorde waar dat twyfel by die venster inkom as vraagstelling by die deur weggewys word. Ons durf ook nie skisofrenies oor die saak wees nie. Teologie kan nie aan 'n kerklike Fakulteit bloot deur en vir belangstellendes of ingeligtes beoefen word en slegs vir eie bevrediging van die teoloog nie. As die resultate daarvan nie bevatlik en verdiskonteerbaar by die lidmate gebring kan word nie, is die hele teologiese bedryf ' $n$ futiele onderneming.

Dit bring ons terug by die teologiese opleiding. Die eerste vraag is hier of die onderskeie dissiplines in die Fakulteit met mekaar die nuwere insigte oor die Bybel deel. Uit die aard van die saak kan 'n mens natuurlik nie verwag dat die nieBybelse dissiplines in dieselfde mate ingelig moet wees oor nuwere Bybelbeskouinge as wat dit die geval by die Bybelwetenskappe is nie.

Nietemin is dit noodsaaklik dat die nie-Bybelse dissiplines minstens wat basiese insigte betref, saambeweeg. Indien nie, sal die gevolge voor die handliggend wees. Dit kan en sal 'n ongesonde kloof en diskrepansie in die Fakulteit laat ontstaan met 'n verwarrende uitwerking op studente en uiteindelik op die Kerk. Die tweede vraag is of ons indien ons wel min of meer met mekaar saamstem, dit regkry om dit ook deel van die studente se denke te maak en dan op so 'n wyse dat hulle dit inderdaad na voltooiing van hulle studie, in die Kerk sal kan oordra. Dikwels wil dit voorkom of die Fakulteit nie hierin slaag nie. Daar blyk dus ' $n$ groot taak vir die toekoms op die Fakulteit se skouers te rus.

Hierdie beskeie bydrae word met waardering aangebied ter ere van ' $n$ teoloog en kerkman, FJ van $\mathrm{Zyl}$, vir wie se nugtere en heldere teologiese denke ek steeds baie groot respek gehad het. 